\title{
A Tribute To Dr. Jyostna Murthy at the World Congress on Cleft and Craniofacial Surgery, February 2017
}

\author{
Ravin Thatte ${ }^{1}$ \\ ${ }^{1}$ Formerly Professor and Head, Department of Plastic Surgery, \\ Lokmanya Tilak Hospital, Mumbai, India
}

Indian J Plast Surg 2020;53:15-16

I first met Jyotsna in 1984 when she was 22 years old and had just completed her medical graduation. I was 44 years old and had just taken over a teaching plastic surgical unit right in the middle of the world's largest slum. She was as direct as one can get in our very first meeting. She said she wanted to learn plastic surgery, and would I give her a job in my unit. Her English was barely passable. I was to realize much later that her education was imparted in her mother tongue, Gujarati, reminding me of myself when I entered the city of Mumbai, then Bombay, from the small towns of Maharashtra 30 years earlier in 1956 . She came from a modest background and lacked what most of us wrongly look for pedigree. She probably had few artificial social graces but her eyes shone even then with sincerity and determination. I had to explain to her that she needed a qualification in general surgery
Address for correspondence Ravin Thatte, MS, FRCS (Edin) Ad Hominem, Plastic and Reconstructive Surgeon, 46, Shirish Co-op. Housing Society, 187, Veer Savarkar Marg, Mahim, Mumbai 400 016, Maharashtra, India (e-mail: rlthatte@gmail.com).

to register for a plastic surgery course. Before I could say as much as a "bye" she thanked me, got up, and left. I had forgotten about her completely when she reappeared 3 years later, having acquired a general surgery degree and renewed her earlier request. This time, she appeared more confident, more fluent in English, and even more determined. I again pleaded my inability, explaining to her that now she needed to qualify through a state-level entrance examination to gain entry into a teaching unit. As in the past, she did not bat an eyelid. She thanked me, got up, and left. Some months later, she reappeared again and left me speechless. She said she had cleared the entrance examination, had stood first, and had opted for my unit in her own right. And then she enquired if I would now kindly sign my consent in the designated column on the admission form.

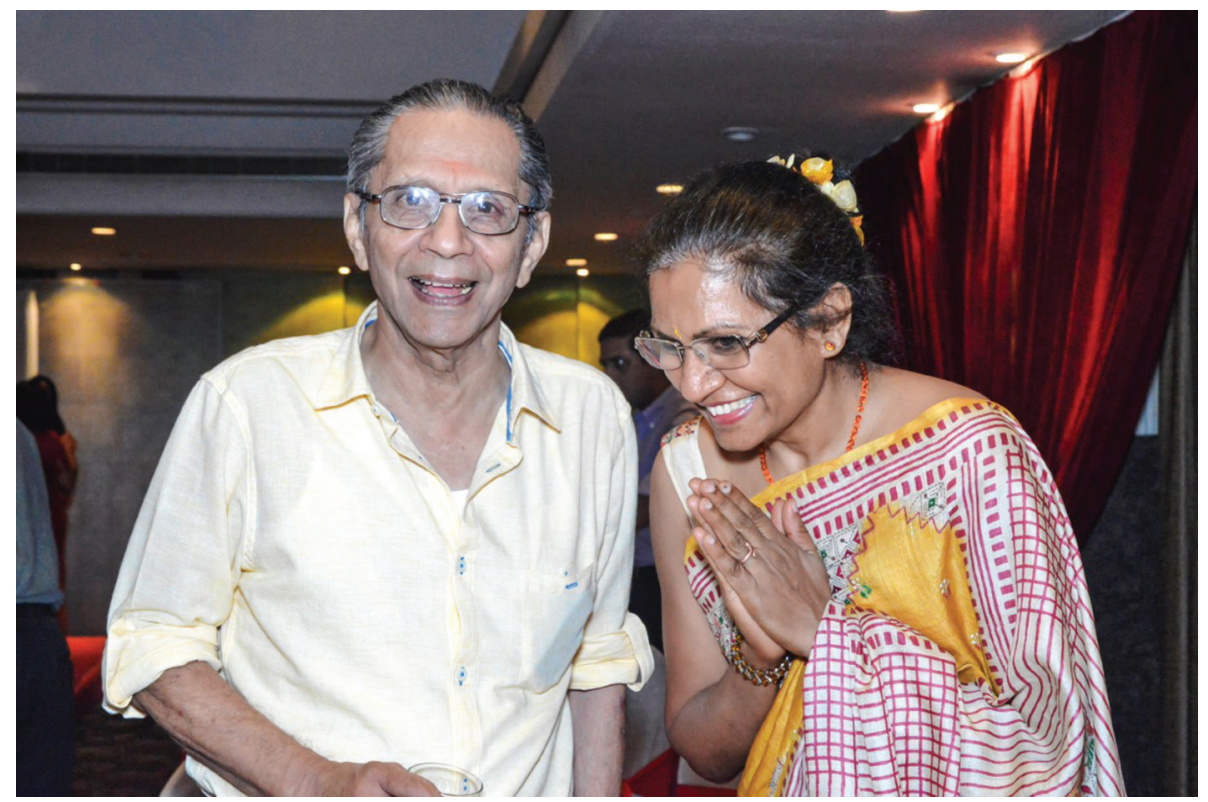

Fig. 1 The mentor and the mentee.

DOI https://doi.org/

$10.1055 / \mathrm{s}-0040-1709812$ ISSN 0970-0358.
(C)2020 Association of Plastic Surgeons of India
License terms

()(1) $\Theta \circledast$ 
I saw her next in the wards and the operation theatre. She took to the unit like fish takes to water. She was also in complete control from the word go. She imbibed with the eagerness of a sponge. She was punctual to a fault; she never demanded more than her share yet fought fiercely for what was her due, but that situation rarely arose because in a manner of speaking, the unit, including me, were in awe of her. She was both formidable and polite. Like one of her colleagues of those years said recently, "she was in a way blinkered. She knew what she came to achieve and saw nothing else." In the event, she was the most outstanding resident that our unit had the privilege of having. Many in my unit have risen high in life, but none was like her. She was special. When she qualified and had to leave, she left behind a gaping void. Only a teacher knows the wrenching feeling that such exits cause. In due course, she travelled abroad, refined her techniques, married a software engineer who is also a gentleman to his fingertips, and raised a son who is accomplished in his own right. She did return to the unit briefly under a central scheme for scientists returning from abroad and then migrated to Chennai to build a hugely productive unit. She always kept in touch and, to my utter amazement, phoned me one day in 2009 that she had been able to bid successfully for this meeting in India. Here too, her persistence paid because an earlier attempt had resulted in a negative outcome. She certainly had help on both occasions but help comes to those who help themselves and whose leadership qualities are ungrudgingly accepted. When the original message came, I wondered if I would live to see this day because that was several years ago, but I did and therefore stand before you. But her story had to have a dark cloud. As the preparations for this meeting began, she was to be visited by the emperor of maladies. But it did not surprise me that she has fought this emperor with her usual grit bringing this meeting to its splendid finale ( - Fig. 1). If there has been an example of the indomitable spirit in my life, "Jyotsna," it is you, you broke more than one barrier. You overcame your circumstances, you were apolitical and did not suffer any fools, and you also defied the gender barrier. I have been in this field now for 50 years, and among the less than half a dozen people who have brought India on the world map of plastic surgery by way of their institutional work, you are certainly the one that comes to my mind. It has been an honor to know you, and I salute you on behalf of all those who have gathered here, as well as the rest of the cleft community. It would be remiss of me to forget Dr. Krishnamoorthy whose efforts for this meeting have been huge. But there too it is Jyotsna who recognized his talent, trusted him, and then delegated responsibility to him, a trait I would like to imagine she absorbed from her old unit as well. She reminds me of the novel atlas shrugged, and she has a little bit of the author of that book Ayn Rand and also a little bit of mother Theresa. She is part Durga, for her aggression and part Saraswati for her educational activities. And since I am older than most of you, I request all of you to give her a standing ovation. Thank you. (This was read by the author during the Inaugural ceremony of 13th International Congress of Cleft Lip and Palate and Related Craniofacial Anomalies, 8-11th Feb, 2017, held at Mahabalipuram, Chennai, India) 